\title{
Principal's Strategy in Overcoming Teaching and Learning Problems at SMAN 9 Tana Toraja
}

\author{
Roberto Patabang Allolangi ${ }^{1)}$, Andi Agustang ${ }^{2)}$ \\ 1) Doctoral Postgraduate Study Program (S3) Education Administration, Universitas Negeri \\ Makassar, Jl. Bonto Langkasa, Makassar-90222, Indonesia \\ 2) Universitas Negeri Makassar, Bonto Langkasa street, Makassar-90222, Indonesia \\ Corresponding Author: Roberto Patabang Allolangi, Email: robertoallolangi@gmail.com
}

History: Received 02/01/2022 | Revised 04/01/2022 | Accepted 18/01/2022 | Published 31/01/2022

\begin{abstract}
Educators as human resources in schools have a very decisive role and are the key to achieving educational goals. The focus of this research problem is how is the principal's strategy to overcome: educators who often give notes to students while the educators concerned hang out outside the classroom?; educators who are not compact?; readiness of learning tools by educators?; Do students hang around a lot during class hours? Research method: observation, interview, documentary. Findings: 1. educators often give notes to students because the classroom atmosphere is boring, students act a lot less respecting educators, the principal does not supervise educators, teaching materials are lacking, and teaching staff is not by their basic education; 2. lack of communication between educators, rare family meetings, jealousy between fellow educators; 3 . almost all educators copy the learning tools of other educators; 4. lack of supervision, picket educators are less active in controlling the situation at school. Conclusion: homerooms need to organize classrooms neatly, maintain cleanliness, and discipline students, principals must control regularly, make joint rules about discipline in class, when educators carry out the teaching and learning process HP is disabled, fulfillment of facilities and infrastructure, holding training, 2. Holding family meetings; 3 . educators make their learning tools or through MGMP; 4. The picket works according to the task.
\end{abstract}

Keywords: Commitment, Responsibility

\begin{abstract}
Abstrak. Tenaga pendidik sebagai sumberdaya manusia yang ada di sekolah mempunyai peranan yang sangat menentukan dan merupakan kunci keberhasilan dalam mencapai tujuan pendidikan. fokus masalah penelitian ini adalah bagaimanakah strategi kepala sekolah mengatasi: tenaga pendidik yang sering memberikan catatan kepada peserta didik sedangkan tenaga pendidik yang bersangkutan nongkrong di luar kelas?; tenaga pendidik yang tidak kompak?; kesiapan perangkat pembelajaran oleh tenaga pendidik?; peserta didik banyak berkeliaran pada saat jam pelajaran sedang berlangsung?. Metode penelitian: observasi, wawancara, dokumenter. Temuan: 1. tenaga pendidik sering memberikan catatan kepada peserta didik karena suasana kelas memjenuhkan, peserta didik banyak bertingkah kurang menghargai tenaga pendidik, tenaga pendidik kurang diawasi oleh kepala sekolah, bahan ajar kurang, serta tenaga pendidik yang mengajar tidak sesuai dengan dasar pendidikannya; 2 . kurang adanya komunikasi antara tenaga pendidik, jarang diadakan pertemuan kekeluargaan, adanya rasa kecemburuan antara sesama tenaga pendidik.; 3. hampir semua tenaga pendidik menjiblak perangkat pembelajaran tenaga pendidik lain.; 4. kurangnya pengawasan, tenaga pendidik piket kurang aktif mengontrol keadaan di sekolah. Kesimpulan: wali kelas perlu untuk menata ruang kelas dengan rapi, menjaga kebersihan serta mendisiplinkan peserta didik, kepala sekolah harus mengontrol secara rutin, membuat peraturan bersama tentang tata tertib di kelas, pada saat tenaga pendidik melaksanakan proses belajar mengajar HP di non aktifkan, pemenuhan sarana dan prasarana, mengadakan diklat, 2. Mengadakan pertemuan kekeluargaan.; 3. tenaga pendidik membuat perangkat pembelajaran sendiri atau melalui MGMP.; 4. Piket berkeja sesuai dengan tugas.
\end{abstract}

Kata kunci: Komitmen dan Tanggungjawab 


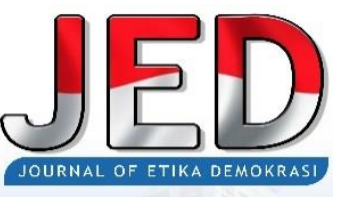

\section{INTRODUCTION}

Educators as human resources in schools have a very important function. They are the key to success (Wahyudin, 2018) in achieving educational goals because educators are managers of implementing the learning process for students. One of the benchmarks for the success of a school in carrying out its mission as an institution that prepares professional and quality graduates who can fill the development needs of the present and the future we will face is the effective and efficient implementation of the teaching and learning process (Myori et al., 2019). For the performance of this learning to run effectively and efficiently by the learning objectives, professional and qualified educators must be provided by the needs of both the number, qualification, and specialization.

The number of educators needed, the existing teaching staff, the advantages and disadvantages of teaching staff in each school illustrate the condition/state of the teaching staff (Bahiroh \& Suud, 2020). The conditions/conditions of the teaching staff can be grouped into four groups, each of which can have an impact on the implementation of the learning process at the school concerned, namely: The first group, schools that have a number of educators as needed, in this group, all subjects have staff the educators are in accordance with the primary education with the number of hours of the subject covered by the teaching staff with a ratio of 1:24-40
ISSN: p-2540-8763 / e-2615-4374

DOI: $10.26618 /$ jed.v\%vi\%i.6794

Vol: 7 Number 1, January 2022

Page: 175-184

hours ( 1 educator has a teaching load of 2440 hours/week); The second group, schools that have excess teaching staff, in this group, all subjects have educators and are the same as the primary education, but there are educators who teach less than 24 hours or there are subjects that are less than 41 hours and there are more than 1 educators who teach; The third group, schools that have a shortage of educators, in this group, there are subjects that there are no teaching staff according to their primary education, there are subjects that have more than 40 hours and only have 1 educator based on education according to the subject the; The fourth group, schools that experience excess and at the same time lack of teaching staff, in this group, there are subjects that have more teaching staff, for example, there is 1 subject whose hours are less than 41 hours but there are more than 1 educators with the same basic education, and For example, there is a lack of teaching staff, there is 1 subject with a total of more than 40 hours, but there is only 1 teaching staff that is in accordance with the primary education. As stated in the "Regulation of the Minister of Education and Culture of the Republic of Indonesia Number 15 of 2018 concerning Fulfilling the Workload of Educators, School Principals, and School Supervisors", the Ministerial Regulation states that the teaching hours for educators must be at least 24 hours face-toface every week. And a maximum of 40 hours per week. 


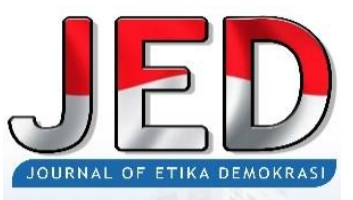

This study discusses the condition of the teaching and learning process at SMAN 9 Tana Toraja; based on observations so far, several educators only provide notes to students while the educators are not in class, educators who are given additional assignments do not do it fully responsive, a lot of students hanging around during lesson hours and the lack of a sense of kinship between educators or lack of cohesiveness between educators. In line with what was stated in the research results of (Mukhlasin, A. 2017). Principal Communication Patterns in Improving Teacher Professional Competence in An-Nizam Islamic Elementary School. 1(1), 54-64.

National development in the field of education is an effort to educate the nation's life (Haling et al., 2018) and improve the quality of Indonesian people who are faithful, devoted, and have noble character and master science, technology, and art in realizing an advanced, just, prosperous, and prosperous society. And civilized based on "Pancasila and the 1945 Constitution of the Republic of Indonesia". To achieve the goal of National Education, which is to educate the nation's life and develop a complete human being, the role of professional educators is very much needed. By the Law of the Republic of Indonesia No. 20 of 2003 Pancasila and the 1945 Constitution of the Republic of Indonesia concerning the National Education System, the position of educators as educators is a professional position. For this reason, the
ISSN: p-2540-8763 / e-2615-4374

DOI: $10.26618 /$ jed.v\%vi\%i.6794

Vol: 7 Number 1, January 2022

Page: 175-184

professionalism of educators is required to continue to develop by the demands of the times, science and technology, as well as the needs of the community (Mukhlasin, 2017), including the need for quality human resources and have the capability to be able to compete in regional, national and international forums, likewise, contained in the Regulation of the Minister of Education and Culture Number 22 of 2016, Law of the Republic of Indonesia No. 20 of 2003 concerning Content Standards. The ministerial regulation states that professional educators are educators who make learning tools: annual programs, semester programs, syllabus, lesson plans, books, structured task sheets and independent activities, handouts, evaluation tools, and grade books.

Educators are professional educators (Dudung, 2018) with the main task of educating, teaching, guiding, directing, training, assessing, and evaluating students in early childhood education through formal education, primary education, and secondary education. Educators have a position as professionals at primary education, secondary education, and early childhood education in the formal education path appointed according to statutory regulations. Educators need to be moved towards a positive, exciting, and productive work atmosphere.

Several problems related to the teaching and learning process (Erwinsyah, 2017), among others: (1) there are differences in the ability of educators in the learning process 


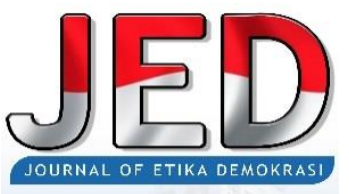

and mastery of knowledge; (2) the absence of appropriate measuring tools to determine the ability of educators; (3) educators teach not in their field of expertise; (4) facilities and infrastructure are inadequate or very lacking; (5) learning tools by educators are not properly prepared; and (6) inadequate welfare of educators. Based on the description in question, the focus of the research problem is "The Principal's Strategy for Overcoming the Problems of the Teaching and Learning Process at SMAN 9 Tana Toraja".

\section{RESEARCH METHODS}

According to Sugiono in (Shidiq \& Choiri, 2019a) that descriptive qualitative research methods are "research that uses natural object conditions (as opposed to experiments) where the researcher was the key instrument, data collection techniques are carried out by triangulation (combined), data analysis was inductive and qualitative research results emphasize meaning rather than generalization. Research subjects are not always people but can be activities (Akhmad Sudrajat, 2010), where the subject of this research was focused on teachers and students at SMAN 9 Tana Toraja. In the context of this research, it was to observe, describe, evaluate and make decisions for the smooth running of the teaching and learning process at SMAN 9 Tana Toraja.

Systematic observation and recording of the symptoms that appear on the object of research (Mania, 2008). Researchers directly
ISSN: p-2540-8763 / e-2615-4374

DOI: $10.26618 /$ jed.v\%vi\%i.6794

Vol: 7 Number 1, January 2022

Page: 175-184

observed the activities of teachers and students in teaching and learning activities. In this way, it was seen directly what problems occur in the learning process.

The collection of secondary data and primary data using the interview method. An interview is a conversation with a specific purpose carried out by two parties, namely the interviewer (interviewer) who asks the question and the interviewee who provides the answer to the question Interview (Shidiq \& Choiri, 2019b).

\section{DISCUSSION}

\section{Teachers Often Give Notes To Students}

Based on interviews conducted by researchers with several teachers who often provide notes to students, it is known that the cause of teachers often giving notes to students is because teachers feel bored with class conditions, teachers feel unappreciated by students, teachers feel unsupervised so that they do their will, teaching materials significantly lacking so that teachers cannot develop lessons, some teachers are less enthusiastic about teaching because the subjects they teach are not following their educational background. From the observations made, namely by visiting the class, it is known that it is true that there are teachers whose job is only to give notes to students while the teacher concerned is outside the classroom, some hang out with teacher friends, some enjoy playing cellphones. 
Following the results obtained, the steps that can be taken are as follows: (1) the teacher feels bored in class; so that the teacher does not feel bored in class, it is obligatory for the homeroom teacher to arrange the classroom neatly, maintain cleanliness and discipline students. The principal will regularly control the tasks given to each homeroom teacher. (2) teachers feel unappreciated by students; principals, students, $11 \mathrm{~K}$ coordinators, and homeroom teachers make joint rules regarding discipline in class, and whoever violates these rules will be penalized according to the rules that have been made, such as students who are not polite to teachers, they will be given guidance and if they still repeat then people will be punished. student parents will be called. (3) the teacher feels unsupervised so that the teacher feels free; the steps to be taken are teachers who often give notes to students or who often leave class will be called and given a warning; when the teacher carries out the teaching and learning process $\mathrm{HP}$ is deactivated; Every day the principal must control the teacher to the class or by controlling it via CCTV, and if the teacher still gives notes to students without any good reason, they will be called and reprimanded starting from verbal to written warnings. (4) fewer teaching materials; The school principal tries his best to meet the needs of school facilities and infrastructure, especially books and other learning media, proposes fulfillment to the South Sulawesi Provincial
Education Office, and proposes fulfillment to the Center. (5) teachers who teach not according to their educational background will prioritize to include training to increase their competence at the Regency, Provincial and Central levels, and teachers who teach not according to their educational background will be accompanied by teachers who are following their educational background or with team teaching.

For schools' smooth teaching and learning process, it is necessary to manage schools with more real principals (Sarifudin, 2019) and implement good school management. Explained that there are several main roles of the Principal in developing a quality culture in managing an influential educational institution, including:

1. Having a clear vision of integrated quality for the organization.

2. Having a clear commitment to quality improvement.

3. Communicating the message of quality.

4. Ensure that the customer's material needs become the center of the organization's policies and work.

5. Lead developing staff.

6. Being careful not to hand over to others when problems arise without seeing evidence as many problems arise from agency policy and not from staff fault.

7. Directing innovation within the organization.

8. Ensure that the clarity of the organizational structure defines 


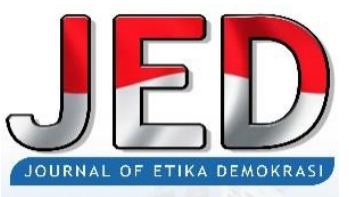

responsibilities and provides appropriate and maximum delegation.

9. Have a firm attitude to remove deviations from the organizational culture.

10. Building active working groups.

11. And establish appropriate mechanisms to monitor or evaluate success.

The Principal is the key to the success of the school in making changes (Muhamad Sholeh, 2003). So that activities to improve programs and learning processes in schools primarily lie with the Principal himself. (Rosyadi \& Pardjono, 2015) state that principals have roles and responsibilities as education managers, education leaders, educational supervisors, and education administrators. According to Government Regulation No. 100 of 2000, competence is the ability and characteristics a civil servant possesses in the form of knowledge, skills, and behavioral attitudes required in carrying out their duties. Competence describes the primary skills, knowledge, and attitudes needed to achieve effective performance in work.

There is a lack of cohesiveness between fellow educators. Based on observations, it can be seen that some educators are simply greeted without joking and seem to ignore each other, some educators work individually, and others don't care about their colleagues, and some even influence their friends who work that why do we have to do that? It's not our job, even though the job requires the help of other people, such as picket educators who
ISSN: p-2540-8763 / e-2615-4374

DOI: $10.26618 /$ jed.v\%vi\%i.6794

Vol: 7 Number 1, January 2022

Page: 175-184

work on pickets. Other educators should also help control students and reprimand students who don't comply, but they are reluctant to say I'm not the picket. It's picket business. After approaching and conducting interviews with the concerned educators, it is known that the causes of incompatibilities between the educators are; variations in age. Some feel that they are more senior, so they think they need to be appreciated more by the easy ones. They think that they are more experienced and know more so that the younger ones feel that the seniors do not appreciate them, lack of communication, come from various disciplines so prestigious with the knowledge they have, do not cooperate, there is a feeling of envy towards fellow educators, for example, if there are educators who are diligent and those who are not diligent, there are those who feel they are not treated the same as other educators. This is supported by the opinion of (Herman, 2021) that the principal, as the manager of educators and education staff, must-have skills in managing, coordinating, and mobilizing subordinates so that they play an active, creative, innovative, and productive role in efforts to improve the quality of education.

Inconsistency also causes the learning process not to be carried out properly. Therefore the principal will hold a family meeting every month (Munawwaro et al., 2020) to provide opportunities for educators to convey what their problems or proposals are, provide an understanding of each 


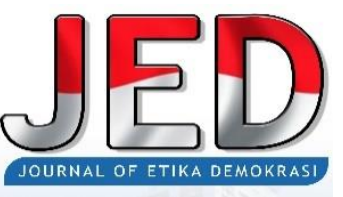

educators so that there are no misunderstandings, giving assignments without discriminating between educators so that jealousy does not occur, providing guidance to educators, if there are educators who do not get along with other educators, the principal will solve it in the best way for educators, call educators and look for the problem and then give a solution.

\section{Learning Tools by Educators}

Do not make their learning tools, even though educators should make their learning tools or groups. Based on observations, it is known that most of the teaching staff and even almost all of the teaching staff copy other people's learning tools. After conducting interviews with educators, it was found that the causes of educators plagiarizing learning tools were that educators did not want to be bothered, did not understand well in making learning tools, lacked facilities and infrastructure such as teaching staff's handbooks on the subjects they were capable of, learning tools were not asked to be shown. Or because the principal or supervisor did not check them.

The tips implemented by school principals related to teaching tools for teaching staff (Suradi, 2018) are: (1) educators do not really understand how to make learning tools; Educators who do not know very well how to make learning tools are included if there is training, and must be conveyed or taught by the waka of the
ISSN: p-2540-8763 / e-2615-4374

DOI: $10.26618 /$ jed.v\%vi\%i.6794

Vol: 7 Number 1, January 2022

Page: 175-184

curriculum to educators on how to make learning tools or the concerned educators learn to those who are already biased in making learning tools. (2) facilities and infrastructure such as books; For the sake of the smooth process of teaching and learning activities, all training subjects must have a handbook for educators, books that do not yet exist will be supplemented by proposing to the National Education Office, Regional Government or the Center. (3) educators do not make learning tools because they are not asked to be shown by the principal or supervisor; so that educators can make learning tools, the principal requires all educators, at the beginning of the new school year or the beginning of the semester in one month the teaching and learning process takes place all educators have finished making learning tools, starting from the annual program, semester and lesson plans. Suppose there are educators who have not yet finished within the specified time limit. In that case, the educators must complete the learning tools at school. The educators must work overtime and be supervised by the principal, provided with facilities such as computers to complete them at school.

Education for early childhood through formal, primary, and secondary education. An educator must be competent and professional in carrying out their duties (Darmadi, 2015) as stated in the 2005 Law on Teachers and Lecturers: "Teachers are professional educators with the main task of educating, 


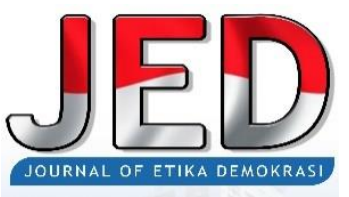

teaching, guiding, directing, training, assessing and evaluating participants. Based on this purpose, the Competency Standard for Educators is a statement about the conditions required, determined, and mutually agreed upon in the form of mastery of knowledge, skills, and attitudes for an academic staff so that it deserves to be called competent (Rini et al., 2016). The competencies that educators must possess are (1) personal competence, including the ability to always present themselves as a good person, permanent, mature, wise, and authoritative, noble, professional, (2) pedagogic competence, namely the ability to manage students which includes the understanding of students, design, and implementation of learning, evaluation of learning outcomes. (3) social competence is the ability of educators as part of the community to interact effectively with parents or guardians of students, fellow educators, and the community as stakeholders from their expert services. (4) professional competencies include personality competencies, areas of expertise, and education (teaching). Meanwhile, matters relating to educational (teaching) competence are the understanding of educators on the characteristics of students and their development, understanding of academic concepts, learning methods, and mastery of evaluation systems (Suparno, 2003). The principal, as a manager, must perform a managerial function (Mahardhani, 2015) by carrying out the process of planning,
ISSN: p-2540-8763 / e-2615-4374

DOI: $10.26618 /$ jed.v\%vi\%i.6794

Vol: 7 Number 1, January 2022

Page: 175-184

organizing, mobilizing, and coordinating. Planning is concerned with determining goals and tips for achieving those goals.

\section{Many students are outside the classroom when the learning process is in progress.}

Based on observations, many students are outside the classroom when the learning process is running almost every day. When interviews were conducted, it was found that the cause of students wandering around was due to lack of supervision. Educators only gave notes so that students felt free to be unsupervised, and picket educators were less active. To control the situation at school, students are rarely reprimanded by educators if they ask permission to urinate so that students hang out outside the classroom longer.

To prevent students from wandering outside the classroom when the learning process is taking place, these are: (1) educators must be in class during class hours if there are educators who have reason to want to do assignments in the office, the tasks to be done in the office below to class. (2) the picket educators are obliged to control going around the school environment and give sanctions to students outside the classroom while the learning process is running. (3) the teaching staff in the class does not allow students to enter and leave the classroom. In line with that contained in the journal (Mahardhani, A. J. 2015). Principal's Ideal 


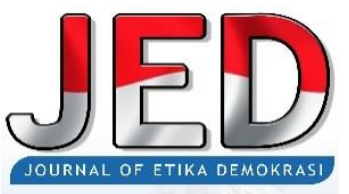

Leadership. Journal of Education and Learning Dimensions, 3(2), 1-4.

\section{CONCLUSION}

Based on the results of the study, it can be concluded that: (1) the cause of educators often giving notes to students is because the class atmosphere is boring, students act less respectfully of educators, school principals do not supervise educators, teaching materials are lacking, and educators who are teaching is not by the primary education. (2) the cause of the inconsistency between fellow educators; lack of communication between educators, rarely held family meetings, jealousy between fellow educators. (3) readiness of learning tools by educators; almost all educators do not make learning tools such as annual programs, semesters, and lesson plans. (4) the reason why many students are outside the classroom when the learning process is running; lack of supervision, educators only providing notes, picket educators are less active in controlling the situation at school.

\section{REFERENCES}

[1] Agustang, A., \& Sahabuddin, J. (2020, October). Model kolaborasi sosial pendidikan karakter di sekolah swasta kecamatan bissappu kabupaten bantaeng. In prosiding seminar dan diskusi pendidikan dasar.

[2] Agustang, A., Suardi, S., Putra, A. D. M., \& Oruh, S. (2021). Pemberdayaan Guru Mata Pelajaran Sosiologi Melalui Literasi Digital Berbasis Quick Response Code di Kecamatan Bissappu Kabupaten
ISSN: p-2540-8763 / e-2615-4374

DOI: $10.26618 /$ jed.v\%vi\%i.6794

Vol: 7 Number 1, January 2022

Page: 175-184

Bantaeng. Abdi: Jurnal Pengabdian dan Pemberdayaan Masyarakat, 3(2), 175-188.

[3] Bahiroh, S., \& Suud, F. M. (2020). Model Bimbingan Konseling Berbasis Religiusitas dalam Mengatasi Kesulitan Belajar Siswa. Islamic Counseling: Jurnal Bimbingan Konseling Islam, 4(1), 31. https://doi.org/10.29240/jbk.v4i1.1170

[4] Darmadi, H. (2015). Tugas, Peran, Kompetensi, Dan Tanggung Jawab Menjadi Guru Profesional. Jurnal Edukasi, 13(2), 161-174.

[5] Dudung, A. (2018). Kompetensi Profesional Guru. JKKP (Jurnal Kesejahteraan Keluarga Dan Pendidikan), 5(1), 9-19. https://doi.org/10.21009/jkkp.051.02

[6] Erwinsyah, A. (2017). Manajemen kelas dalam meningkatkan efektifitas proses belajar mengajar. TADBIR: Jurnal Manajemen Pendidikan Islam, 5(2), 88-105. https://www.journal.iaingorontalo.ac.id/inde x.php/tjmpi/article/view/392/309

[7] Haling, S., Halim, P., Badruddin, S., \& Djanggih, H. (2018). Perlindungan Hak Asasi Anak Jalanan Dalam Bidang Pendidikan Menurut Hukum Nasional Dan Konvensi Internasional. Jurnal Hukum \& Pembangunan, $\quad 48(2), \quad 361$. https://doi.org/10.21143/jhp.vol48.no2.1668

[8] Herman, H. (2021). Keterampilan Kepemimpinan Kepala Madrasah Dalam Pengelolaan Guru Dan Karyawan. Bidayah: Studi Ilmu-Ilmu Keislaman, 177. https://doi.org/10.47498/bidayah.v11i02.409

[9] Mahardhani, A. J. (2015). Kepemimpinan Ideal Kepala Sekolah. Jurnal Dimensi Pendidikan Dan Pembelajaran, 3(2), 1-4.

[10] Mukhlasin, A. (2017). Pola Komunikasi Kepala Sekolah Dalam Meningkatkan Kompetensi Profesionalisme Guru Di SD Islam An-Nizam. 1(1), 54-64.

[11] Munawwaroh, K., Silvia, E., Wahyuni, U., Dewi, S., \& Mayasari, M. (2020). Peningkatan Performa Sekolah Dasar Melalui Program Pelatihan Guru dan Kepala Sekolah di Kota Jambi. Seminar Nasional ADPI Mengabdi Untuk Negeri, 1(1), 250255. https://doi.org/10.47841/adpi.v1i1.64 
[12] Myori, D. E., Hidayat, R., Eliza, F., \& Fadli, R. (2019). Peningkatan Kompetensi Guru dalam Penguasaan Teknologi Informasi dan Komunikasi melalui Pelatihan Pengembangan Media Pembelajaran Berbasis Android. JTEV (Jurnal Teknik Elektro Dan Vokasional), 5(2), 102-109.

[13] Rini, D. S., Justitia, D., \& Setiawaty, D. (2016). KOMPETENSI KEPRIBADIAN GURU BK (Survei pada Guru Bimbingan dan Konseling Sekolah Menengah Pertama dan Sederajat Se-Kecamatan Citeureup). Insight: Jurnal Bimbingan Konseling, 5(1), 27. https://doi.org/10.21009/insight.051.05

[14] Rosyadi, Y. I., \& Pardjono, P. (2015). Peran Kepala Sekolah Sebagai Manajer Dalam Meningkatkan Mutu Pendidikan Di Smp 1 Cilawu Garut. Jurnal Akuntabilitas Manajemen Pendidikan, 3(1), 124-133. https://doi.org/10.21831/amp.v3i1.6276

[15] Sarifudin. (2019). Islamic Management: Jurnal Manajemen Pendidikan Islam, Vol. 02, No. 01, Januari 2019. Islamic Managemen, 02(01).

[16] Shidiq, U., \& Choiri, M. (2019). Metode Penelitian Kualitatif di Bidang Pendidikan. In Journal of Chemical Information and Modeling (Vol. 53, Issue 9). http://repository.iainponorogo.ac.id/484/1/M ETODE PENELITIAN KUALITATIF DI BIDANG PENDIDIKAN.pdf

[17] Suradi, A. (2018). Kinerja Guru Pendidikan Agama Islam Di Sekolah Academic Supervision of Headmaster on Teacher Performance of Islamic Religious in Elementary School 79 Bengkulu City. AULADUNA: Jurnal Pendidikan Dasar Islam, 5(1), 13-29.

[18] Suardi, S., Agustang, A., \& Jumadi, J. (2021). Dominasi Sekolah Negeri Terhadap Sekolah Swasta Sebagai Penyebab Kekerasan Simbolik Terhadap Siswa Sekolah Swasta. Jurnal Ilmiah Muqoddimah: Jurnal Ilmu Sosial, Politik dan Hummanioramaniora, 5(2).

[19] Wahyudin, W. (2018). Optimalisasi Peran Kepala Sekolah dalam Implementasi Kurikulum 2013. Jurnal Kependidikan, 6(2), 249-265.

https://doi.org/10.24090/jk.v6i2.1932 